\title{
Glucocorticoids Induce Mineralization Coupled with Bone Protein Expression without Influence on Growth of a Human Osteoblastic Cell Line
}

\author{
Kousuke Iba* ${ }^{\dagger, 1}$, Hideki Chiba*, ${ }^{\dagger}$, Norimasa Sawada*, Seiichi Hirota ${ }^{\ddagger}$, Seiichi Ishii ${ }^{\dagger}$, and \\ Michio Mori* \\ Departments of ${ }^{*}$ Pathology and ${ }^{\dagger}$ Orthopaedic Surgery, Sapporo Medical University School of Medicine, \\ Sapporo 060; and $\ddagger$ Department of Pathology, Osaka University Medical School, Suita 565, Japan
}

Key words: osteoblasts/human/cell line/mineralization/glucocorticoids

\begin{abstract}
$A B S T R A C T$. Mineralization was induced by glucocorticoid treatment in a human osteoblastic cell line derived from normal bone in vitro, designated SV-HFO, immortalized with simian virus 40 (CHIBA, H. et al. (1993). Jpn. J. Cancer Res., 84: 290-297). Mineralization was revealed by electron microscopy, von Kossa staining and electron spectroscopic analysis, which indicated that the $\mathrm{Ca} / \mathrm{P}$ ratio was approximately 1.70 , corresponding to the value of hydroxyapatite. The effect was dose- $\left(10^{-8}-10^{-6} \mathrm{M}\right)$ and time-dependent $($ days $7-28)$, was greatest at day 28, and was preceded by expression of alkaline phosphatase (ALP) and osteopontin (OPN). The ALP activity induced was highest at day 7, whereas OPN reached its highest level at day 28 . When the induction of ALP activity was inhibited by $10^{-4} \mathrm{M}$ levamisole, mineralization of SV-HFO cells by glucocorticoid treatment was markedly reduced, suggesting that elevated ALP activity in the early phase is important in the mineralization of human osteoblastic cells. Glucocorticoid treatment did not alter cell proliferation. These results indicated that glucocorticoids play crucial roles in the formation of mineralized matrix in human osteoblasts by inducing differentiation of SV-HFO cells without modulating their proliferative activity.
\end{abstract}

The process of bone formation is mostly studied in vitro by using established osteoblastic cells and osteosarcoma cell lines $(11,42,47)$. It has been proposed that mineralized bone-like tissue is formed through sequential events which involve proliferation and differentiation of osteoblastic cells $(32,38,39,43,50)$. Normal human osteoblastic cells, which were isolated from periosteum $(28,45)$, trabecular bones $(3,10,40)$ or bone marrow $(2,13,19,30)$, have been used to study bone formation in human bone in vitro. However, these cells frequently show alterations in phenotypic properties with increasing passage number, and the cells, including

\footnotetext{
1 To whom correspondence should be addressed at Department of Pathology, Sapporo Medical University School of Medicine, S.1, W.17, Chuo-ku, Sapporo 060, Japan.

Abbreviations: alkaline phosphatase, ALP; osteopontin, OPN; osteocalcin, $\mathrm{OC} ; 1 \alpha, 25$-dihydroxyvitamin $\mathrm{D}_{3}, 1,25(\mathrm{OH})_{2} \mathrm{D}_{3}$; all-trans retinoic acid, RA; transforming growth factor- $\beta_{1}$, TGF- $\beta_{1}$; basic fibroblast growth factor, bFGF; interleukin-4, IL-4; $\alpha$-minimal essential medium, $\alpha$-MEM; fetal bovine serum, FBS; $\beta$-glycerophosphate, $\beta$ GP; N-2-hydroxyethylpiperazine- $\mathrm{N}^{\prime}$-ethane sulfonic acid, HEPES; dexamethasone, Dex; hydrocortisone, $\mathrm{HC}$; insulin, transferrin and selenious acid, ITS; calcium, Ca; phosphorus, $\mathrm{P}$; electron spectroscopy for chemical analysis, ESCA; bromodeoxyuridine, BrdU; bovine serum albumin, BSA; saline sodium citrate, SSC; osteonectin, ON; $\alpha 1$ (I) procollagen, Col I; sodium dodecyl sulfate, SDS; digoxigenin, DIG.
}

HOBIT cells, which are transfected with SV-40 large T antigen (27), eventually lose proliferative activity. Although several cell lines from human osteosarcomas are also available, these cells do not fully express phenotypes of normal osteoblasts. In this sense, immortalized cell lines from normal human bone have long been desired to elucidate the molecular mechanisms by which human bone tissues are formed and the therapeutic effects of various agents on ossification.

Recently, we have established a novel osteoblastic cell line, designated SV-HFO, from normal human calvaria by immortalization with simian virus 40 (14). The SVHFO cell line has a mesencymal nature, as revealed by phase-contrast, electron microscopic and immunohistochemical analyses. The cells produce low-level alkaline phosphatase (ALP) activity and osteocalcin (OC), and respond to $1 \alpha, 25$-dihydroxyvitamin $\mathrm{D}_{3}\left(1,25(\mathrm{OH})_{2} \mathrm{D}_{3}\right)$, all-trans retinoic acid (RA) and transforming growth factor- $\beta_{1}\left(\right.$ TGF- $\left.\beta_{1}\right)$ (14-17).

In the present study, we examined the process of mineralization in the SV-HFO cell line in vitro by treating the cells with glucocorticoids $(8,9,20,33)$, $1,25(\mathrm{OH})_{2} \mathrm{D}_{3}(4,34), \mathrm{RA}$, basic fibroblast growth factor (bFGF) $(35,37)$, TGF- $\beta_{1}(36,46)$ and interleukin-4 (IL4) (45). We found that glucocorticoids induced mineralization of SV-HFO cells in a dose- and time-dependent 
Table I. EFFeCtS of FACTORS ON MINERALIZATION OF MATRIX SYNTHESIZED BY SV-HFO CELlS in vitro.

\begin{tabular}{|c|c|c|c|c|c|c|c|c|c|c|c|c|c|c|}
\hline \multirow{3}{*}{$\begin{array}{l}\text { Treatment } \\
\text { (Concentration) }\end{array}$} & - & Vit $D_{3}$ & & & $\mathrm{H}$ & & & & & & & & & \\
\hline & & $\mathrm{M}$ & \multicolumn{2}{|c|}{$\mathrm{M}$} & \multicolumn{2}{|c|}{ M } & \multicolumn{2}{|c|}{$\mathbf{M}$} & \multicolumn{2}{|c|}{$\mathrm{ng} / \mathrm{ml}$} & \multicolumn{2}{|c|}{$\mathrm{ng} / \mathrm{ml}$} & \multicolumn{2}{|c|}{$\mathrm{ng} / \mathrm{ml}$} \\
\hline & & $10^{-9} \quad 10^{-7}$ & $10^{-7}$ & $10^{-6}$ & $10^{-7}$ & $10^{-6}$ & $10^{-9}$ & $10^{-7}$ & 0.5 & 5 & 1 & 10 & 1 & 10 \\
\hline
\end{tabular}

Mineralization

Cells were cultured in $\alpha$-MEM containing $10 \%$ FBS, $10 \mathrm{mM} \beta$-glycerophosphate and one of the above factors for 4 weeks. Mineralization was determined by von Kossa staining.

Vit $\mathrm{D}_{3}: 1 \alpha, 25$-dihydroxyvitamin $\mathrm{D}_{3}$, Dex: dexamethasone, $\mathrm{HC}$ : hydrocortisone, RA: all-trans retinoic acid

TGF- $\beta_{1}$ : transforming growth factor- $\beta_{1}$, bFGF: basic fibroblast growth factor, IL-4: interleukin-4

manner and that elevation of ALP activity in the early stage is crucial for the development of mineralization.

\section{MATERIALS AND METHODS}

Cell culture. The SV-HFO cell line was established as described previously (14). The cells at passage 14 were seeded at a cell density of $1 \times 10^{4}$ cells $/ \mathrm{cm}^{2}$ on $100-\mathrm{mm}$ or $35-\mathrm{mm}$ culture dishes (Corning Glass Works, Corning, NY) in $\alpha$-minimal essential medium ( $\alpha$-MEM; Gibco Laboratories, Grant Island, NY) supplemented with 10\% fetal bovine serum (FBS; JRH Bioscience, Lenexa, KS), $10 \mathrm{mM} \beta$-glycerophosphate ( $\beta$-GP; Sigma Chemical Co., St. Louis, MO), $100 \mathrm{U} / \mathrm{ml}$ penicillin and $100 \mu \mathrm{g} / \mathrm{ml}$ streptomycin (Immuno Biological Laboratories, Fujioka, Japan) and $20 \mathrm{mM} \mathrm{N}$-2-hydroxyethylpiperazine-N'-ethane sulfonic acid (HEPES; Sigma). To determine the culture conditions inducing mineralization of this cell line, the cells were treated with $1,25(\mathrm{OH})_{2} \mathrm{D}_{3}$ (Biomol Research Laboratories, Inc., Plymouth Meeting, PA), dexamethasone
(Dex; Orgadorone, Sankyou Corp., Tokyo, Japan), hydrocortisone (HC; Sigma), RA (Sigma), TGF- $\beta_{1}$ (Sigma), bFGF (Seikagaku Corp., Tokyo, Japan) or IL-4 (Upstate Biological Research, Inc., Lake Placid, NY) at various concentrations from the 2 nd day to the 28 th day after seeding. These cells were cultured at $37^{\circ} \mathrm{C}$ in a humidified atmosphere of $95 \%$ air and 5\% $\mathrm{CO}_{2}$, and medium was renewed every 2 nd or $3 \mathrm{rd}$ day.

For serum-free culture, the cells were plated on dishes coated with $2 \mu \mathrm{g} / \mathrm{cm}^{2}$ type I collagen (Vitrogen 100; Colagen Corp., Palo Alto, CA) in $\alpha$-MEM supplemented with $0.5 \%$ bovine serum albumin (Albumax; Gibco), ITS (containing 5 $\mu \mathrm{g} / \mathrm{ml}$ insulin, $5 \mu \mathrm{g} / \mathrm{ml}$ transferrin and $5 \mathrm{ng} / \mathrm{ml}$ selenious acid; Collaborative Research Inc., Bedford, MA), $10 \mathrm{mM} \beta$ GP and $20 \mathrm{mM}$ HEPES.

Histological detection of minerals. The cells were rinsed with PBS, fixed in $20 \%$ Formalin overnight, and stained by alizarin red or the von Kossa technique for the detection of minerals. To demonstrate mineral deposits on cross sections of cell layers, the fixed cells were dehydrated, embedded in par-

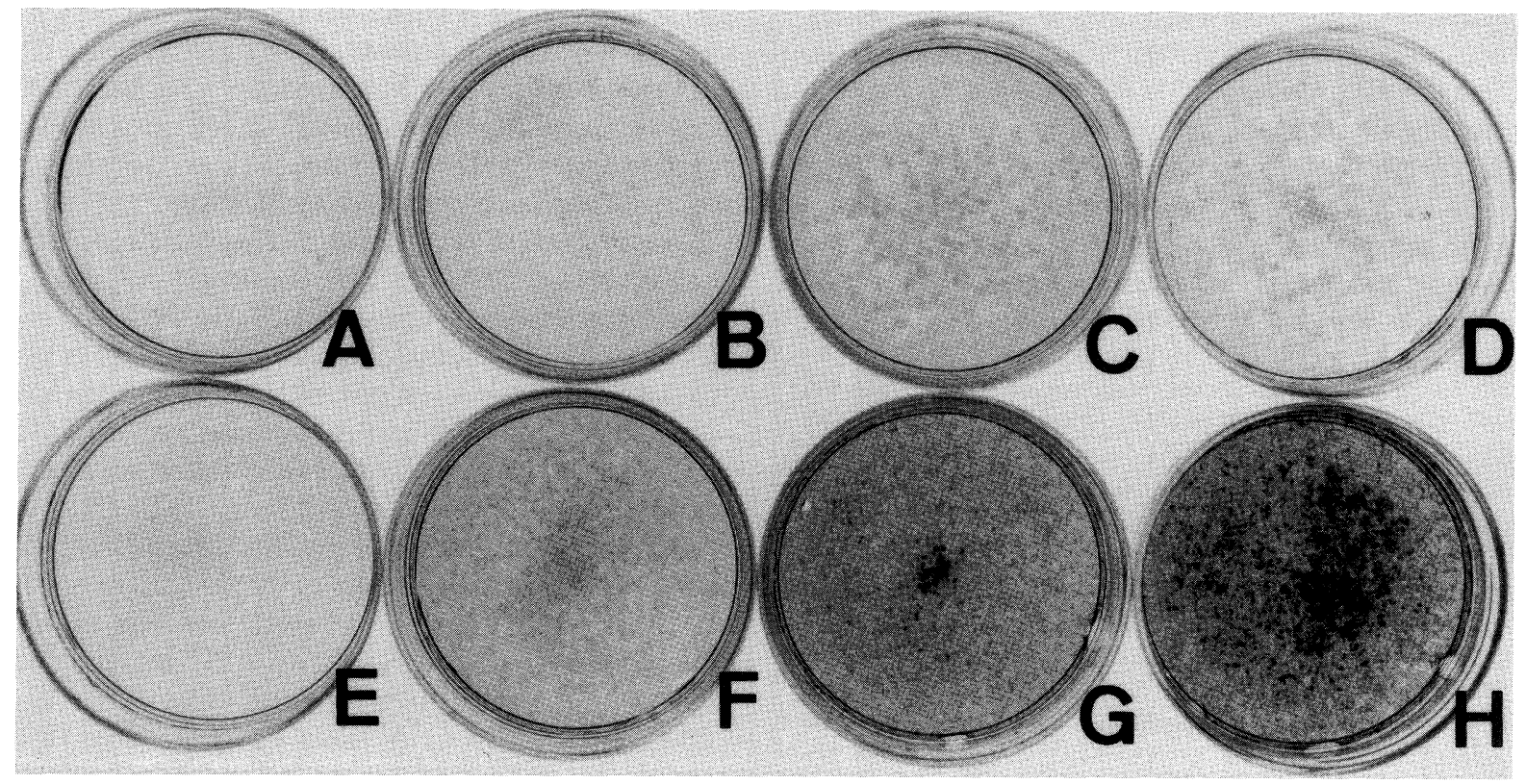

Fig. 1. Von Kossa staining of SV-HFO cells cultured with (E-H) or without (A-D) 10 $10^{-6}$ M Dex for 7 (A, E), 14 (B, F), 21 (C, G) or 28 (D, H) days. 
affin, and sectioned into $4 \mu \mathrm{m}$ slices. The sections were then stained by the above methods, and examined under a light microscope.

Biochemical detection of minerals. After the cells were washed twice with Hanks' balanced salt solution ( $\mathrm{pH} 7.4$ ), minerals deposited in the extracellular matrix were extracted with $0.8 \mathrm{ml}$ of $5 \%$ perchloric acid at $4^{\circ} \mathrm{C}$. The amount of calcium $(\mathrm{Ca})$ was spectrophotometrically measured by the $o$-cresolphthain Complexone method (22), and that of phosphorus (P) was determined by the colorimetric method of Chen et al. (12).

Ultrastructural analysis. For transmission electron microscopy, the cells were fixed in a mixture of $1 \%$ glutaraldehyde and $4 \%$ paraformaldehyde in cacodylate buffer $(\mathrm{pH} \mathrm{7.4)}$ at $4^{\circ} \mathrm{C}$ for $30 \mathrm{~min}$. They were then postfixed with $1 \% \mathrm{OsO}_{4}$, dehydrated, and embedded in Epon 812. Ultrathin sections were stained with uranyl acetate and lead citrate, and examined with a JEOL 1200-Ex transmission electron microscope.

Electron spectroscopy for chemical analysis (ESCA). The cells were fixed in a mixture of $1 \%$ glutaraldehyde and $4 \%$

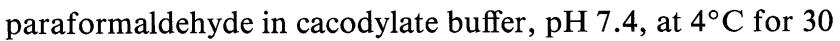
min, dehydrated, and dried at room temperature. These cell layers were scraped and examined for the compositions of $\mathrm{Ca}$ and $\mathrm{P}$ with an electron spectrometer (Shimazu ESCA-850, Kyoto Japan).

Analysis of growth properties. At the 1st, 3rd, 5th, 7th, 14th, 21st and 28th days after plating, cultured cells were dispersed in $0.05 \%$ trypsin and $0.02 \%$ EDTA, and the cell number was counted in a hemocytometer using $0.15 \%$ trypan blue in PBS. For monitoring of DNA synthesis, the cells were incubated with bromodeoxyuridine (BrdU) for $12 \mathrm{hr}$, fixed in absolute ethanol, and BrdU incorporation was determined using a cell proliferation kit (Amersham International Plc., Amersham, UK).

Measurement of ALP activity. The cells were rinsed twice with PBS, scraped in $0.5 \mathrm{ml}$ of a solution containing $0.1 \%$ Triton X-100, $10 \mathrm{mM}$ Tris- $\mathrm{HCl}$ (pH 7.5), $1 \mathrm{mM} \mathrm{MgCl}_{2}$ and $0.02 \% \mathrm{NaN}_{3}$, and sonicated for $5 \mathrm{sec}$. The cells were centrifuged at $10,000 \mathrm{~g}$ at $4^{\circ} \mathrm{C}$ for $5 \mathrm{~min}$, and the supernatant was kept frozen at $-20^{\circ} \mathrm{C}$ until use. ALP activity was spectrophotometrically measured using $p$-nitrophenyl phosphate as a
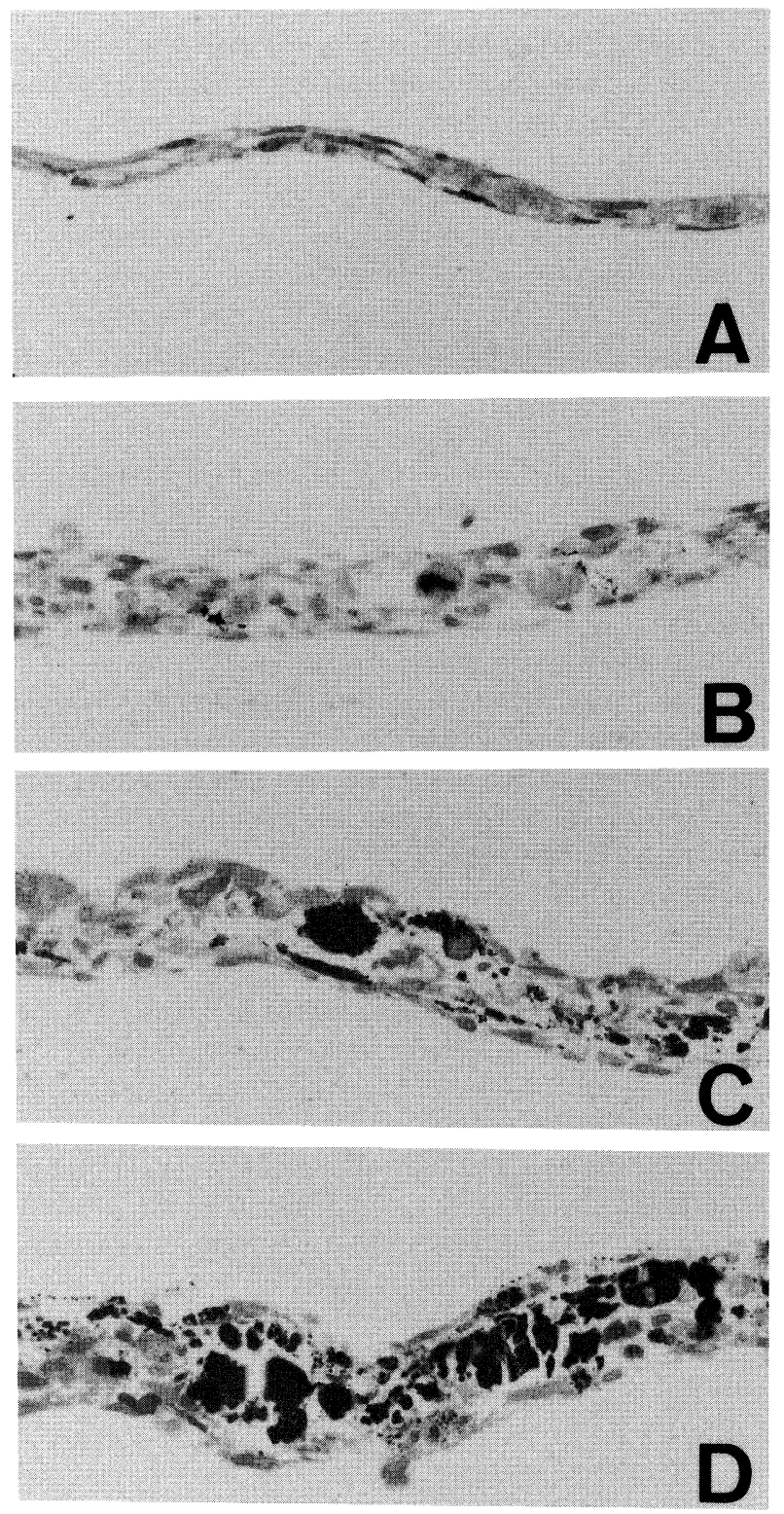

Fig. 2. Von Kossa staining of cross sections of SV-HFO cell layers cultured with $10^{-6} \mathrm{M}$ Dex for 7 (A), 14 (B), 21 (C) or 28 (D) days.

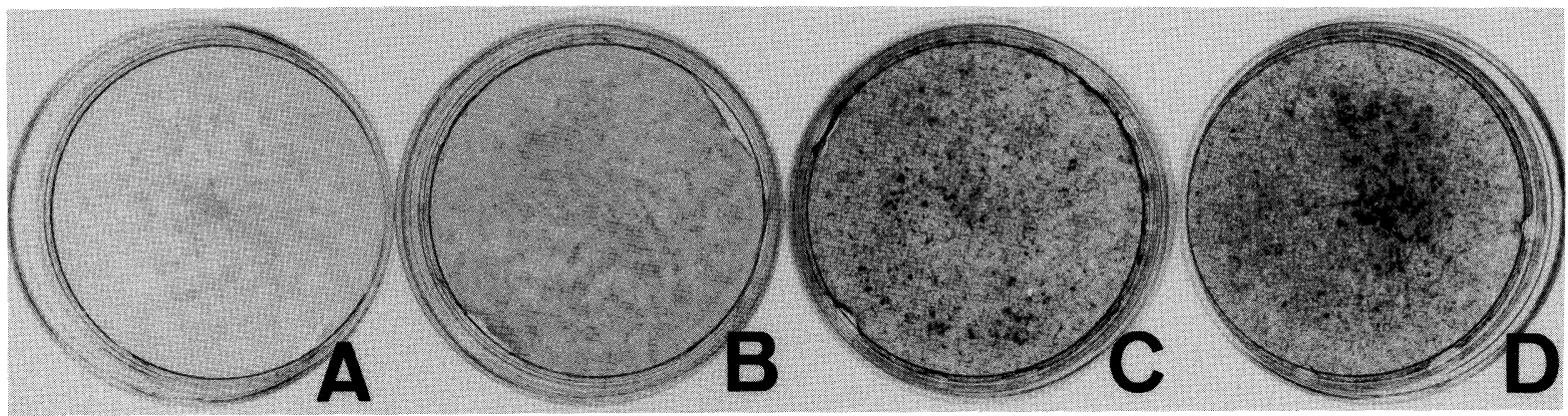

Fig. 3. Von Kossa staining of SV-HFO cells cultured for 28 days, in the absence (A) or presence of $10^{-8} \mathrm{M}(\mathrm{B}), 10^{-7} \mathrm{M}(\mathrm{C})$ or $10^{-6} \mathrm{M}(\mathrm{D}) \mathrm{Dex}$. 
substrate. The content of cellular protein was measured by using a Pierce BCA protein assay kit (Pierce Chemical Co., Rockford, IL) using bovine serum albumin (BSA) as a standard. ALP activity was expressed as nanomoles $/ \mathrm{min} / \mathrm{mg}$ protein.

Measurement of osteocalcin synthesis. To avoid contamination of serum osteocalcin (OC) from FBS, the medium was changed to serum-free medium $24 \mathrm{hrs}$ before measurement. The amount of OC secreted into the culture medium was determined by radioimmunoassay using a commercially available kit (CIS Biointernational, Gif-Sur-Yvette, France). Results were expressed as nanograms/dish.

Northern blot analysis. Total RNAs were isolated from cell cultures using the single-step thiocyanate-phenol-chloroform extraction method (18) as modified by Xie and Rothblum (49). For electrophoresis, $10 \mu \mathrm{g}$ of total RNA was loaded on $1 \%$ agarose gel containing $0.5 \mu \mathrm{g} / \mathrm{ml}$ ethidium bromide. The RNA was capillary-blotted in $20 \times$ saline sodium citrate (SSC) onto nylon membranes (Hybond-N; Amersham Corp.) and fixed by UV light.

Human osteonectin $(\mathrm{ON})$ cDNA containing a 526-bp fragment (1446 to 1971) and human osteopontin (OPN) cDNA containing a 336-bp fragment (862 to 1197) were reverse-transcribed from mRNA of adult human bone tissue, followed by polymerase chain reaction, and subcloning into pBluescript KS- (23). The base sequences were identical to those of human ON and human OPN cDNAs described previously $(44,51)$. Human cDNA probes for the following sources were also used; $\alpha 1$ (I) procollagen (Col I) kindly provided by Dr. Yasuko Koshihara (Department of Biosignal Research, Tokyo Metropolitan Institute of Gerontology), OC generously provided by Dr. John M. Wozney (Genetics Institute, Inc.) and Dr. Shintaro Nomura (Department of Pathology, Osaka University Medical School), and ALP from the American Type Culture Collection.

For the detection of mRNAs of Col I and ALP, membranes were prehybridized in a solution containing $50 \%$ formamide, $0.9 \mathrm{M} \mathrm{NaCl}, 0.1 \mathrm{M} \mathrm{NaPO}_{4}$ (pH 7.4), $1 \%$ sodium dodecyl sulfate (SDS), $10 \mu \mathrm{g} / \mathrm{ml}$ herring sperm DNA and $5 \times$ Denhart's solution at $42^{\circ} \mathrm{C}$ for $4 \mathrm{hr}$, and then hybridized overnight at $42^{\circ} \mathrm{C}$ in the same solution containing ${ }^{32} \mathrm{P}$-labeled cDNA probes. The membranes were washed twice in $2 \times$ SSC containing $0.1 \% \mathrm{SDS}$ for $5 \mathrm{~min}$ at room temperature and twice in $2 \times \mathrm{SSC}$ containing $1 \% \mathrm{SDS}$ for $30 \mathrm{~min}$ at $68^{\circ} \mathrm{C}$ before exposure.

To detect mRNA of ON, OPN and OC, digoxigenin (DIG)labeled RNA probes were prepared from their cDNAs using an RNA labeling kit (Boehringer Mannheim, Mannheim, Germany), and hybridization, washing and chemiluminescent detection were carried out following the DIG luminescent proto-

Fig. 4. Von Kossa staining indicating the effect of Dex withdrawal on the mineralization in SV-HFO cells. The cells were treated with $10^{-6} \mathrm{M}$ Dex for $1(\mathrm{~B})$ or $3(\mathrm{C})$ days, and subsequent cultured without Dex until day 28. Control cells were constantly treated with (D) or without (A) $10^{-6} \mathrm{M}$ Dex for 28 days.
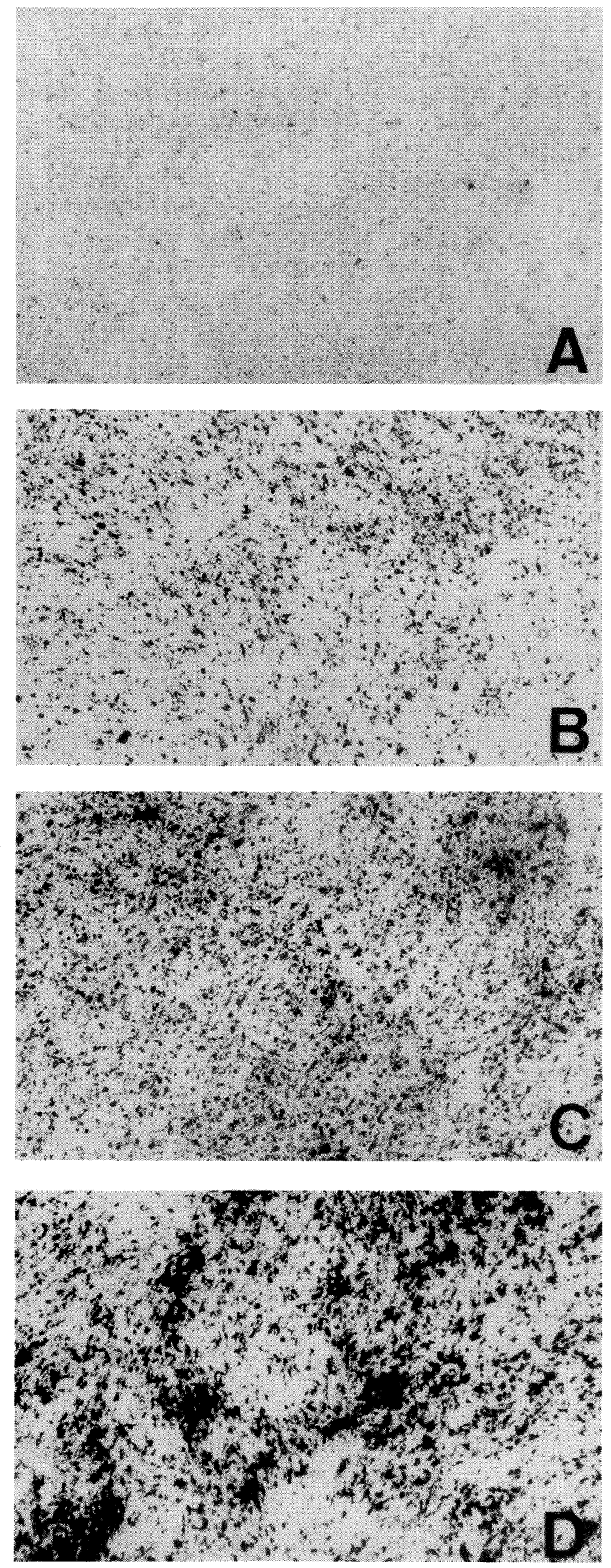

Fig. 4. 
col (24).

Levamisole treatment. To elucidate the role of ALP in mineralization of SV-HFO cells, the cells reaching a confluent density were treated with $10^{-6} \mathrm{M}$ Dex in the presence of $10^{-4}$ M levamisole (Sigma) for 7 days, and cultured without Dex and levamisole for 14 consecutive days. ALP activity was measured by the above method at the $2 \mathrm{nd}$, 4th, 7th, 14th and 21st days after treatment, and minerals were detected by the von Kossa technique at the 21 st day after treatment.

Statistical analysis. The data was statistically analyzed using an unpaired, double-sided t-test. All data were represented as mean values of four different dishes.

\section{RESULTS}

Culture conditions inducing mineralization of $S V$ $H F O$ cells in vitro. To determine the culture conditions inducing mineralization of SV-HFO cells in vitro, they were cultured for 28 days in $\alpha$-MEM supplemented with $10 \%$ FBS and $10 \mathrm{mM} \beta$-GP in the presence of $1,25(\mathrm{OH})_{2} \mathrm{D}_{3}$, Dex, HC, RA, TGF- $\beta_{1}$, bFGF or IL-4 at various concentrations. The deposition of minerals was determined by von Kossa and alizarin red staining. As shown in Table I, mineralization of matrix synthesized by SV-HFO cells required treatment with either Dex or $\mathrm{HC}$. In addition, the cells at passage 60 , which were im-

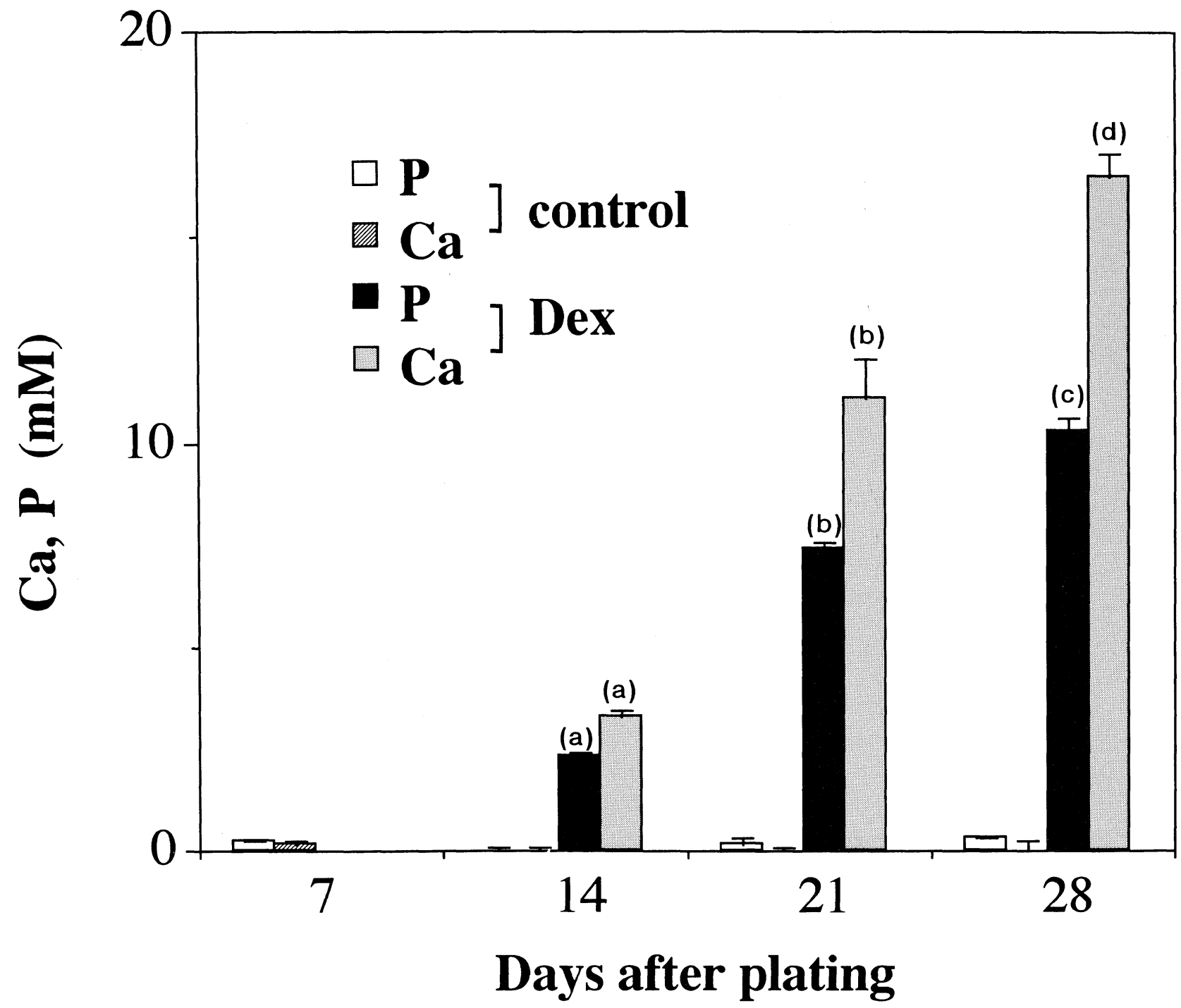

Fig. 5. Amounts of $\mathrm{Ca}$ and $\mathrm{P}$ in SV-HFO cells cultured with or without $10^{-6} \mathrm{M}$ Dex for $7,14,21$ or 28 days. The figures show mean \pm SD of four different dishes with duplicate determinations. (a) Significantly different from the values of cells cultured with Dex for 7 days (P<0.001). (b) Significantly different from the values of cells cultured with Dex for 14 days $(\mathrm{P}<0.001)$. (c), (d) Significantly different from the values of cells cultured with Dex for 21 days ((c) $\mathrm{P}<0.05$, (d) $\mathrm{P}<0.001$ ). 
mortalized after crisis, also formed mineralized tissues under the above conditions. Based on these findings, we further examined changes in the bone protein expression of SV-HFO cells cultured in the medium supplemented with $10 \%$ FBS, $10 \mathrm{mM} \beta$-GP and Dex.

Histological detection of minerals. When SV-HFO cells were cultured with $10^{-6} \mathrm{M}$ Dex, a light-dense structure was observed under a phase-contrast microscope at day 10 (data not shown). Mineralized tissue was detected as black granules by von Kossa staining at day 14 , and developed with time. Though both control and Dex-treated cells formed multilayers, only Dex-treated cells produced mineralized bone-like tissues (Figs. 1 and 2). Dex-induced mineralization of the cells occurred when the cells cultured in the absence of serum as well as in the presence of serum (data not shown).

Dex induced mineralization in a dose-dependent manner, with the maximal effect at $10^{-6} \mathrm{M}$ (Fig. 3). Only 1- day treatment of cells with $10^{-6} \mathrm{M}$ Dex was sufficient to induce mineralization, although the degree was low compared to that of cells continuously treated with Dex. (Fig. 4). Mineralization induced by Dex always required about 2 weeks after the beginning of Dex addition even after the cells reached confluent cell density, regardless of the concentration of Dex.

Biochemical detection of minerals. $\mathrm{Ca}$ and $\mathrm{P}$ became biochemically detectable in cultures treated with $10^{-6} \mathrm{M}$ Dex at day 14, and their amounts increased significantly during culture. $\mathrm{Ca}$ and $\mathrm{P}$ acummulation was not detected in control culture (Fig. 5). The effect of Dex on mineral deposition was dose-dependent, being maximal at $10^{-6} \mathrm{M}$ (Fig. 6). These data were consistent with the results obtained from von Kossa staining.

Ultrastructural analysis. Transmission electron microscopy was performed on the SV-HFO cells cultured in the presence or absence of Dex for 14 or 28 days. Elec-

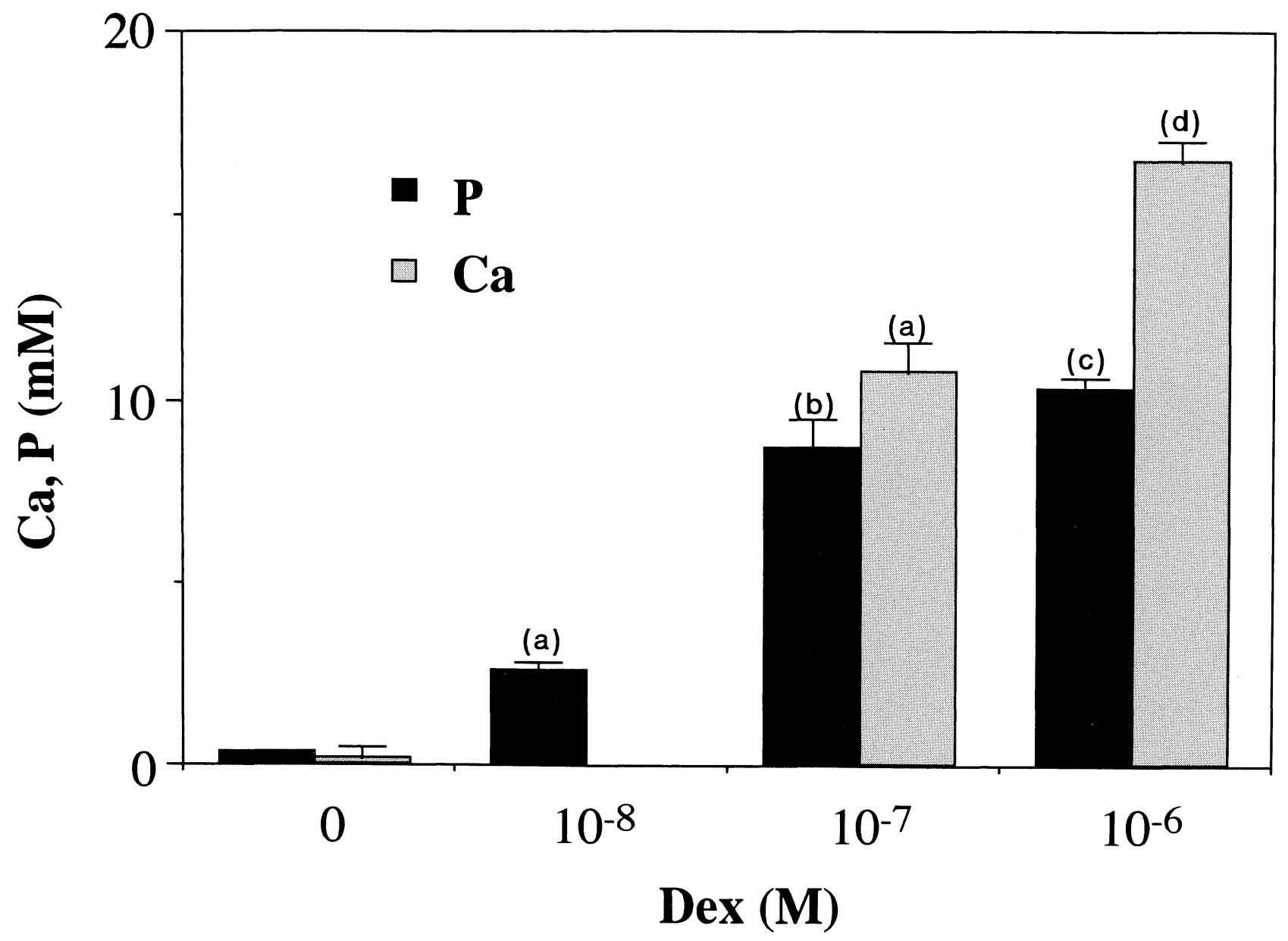

Fig. 6. Amounts of $\mathrm{Ca}$ and $\mathrm{P}$ in SV-HFO cells cultured for 28 days in the absence or presence of $10^{-8} \mathrm{M}, 10^{-7} \mathrm{M}$ or $10^{-6} \mathrm{M}$ Dex. The figures show mean \pm SD of four different dishes with duplicate determinations. (a) Significantly different from the values of cells cultured with Dex $(\mathrm{P}<0.001)$. (b) Significantly different from the values of cells cultured with $10^{-8} \mathrm{M}$ Dex $(\mathrm{P}<0.001)$. (c), (d) Significantly different from the values of cells cultured with $10^{-7} \mathrm{M}$ Dex ((c) $\mathrm{P}<0.01$, (d) $\mathrm{P}<0.001$ ). 
tron-dense deposits were observed among extracellular collagen fibrils of osteoblastic cells in Dex-treated cultures (Fig. 7), but not in the control. These structures were conspicuous at day 28 compared to day 14 .

Electron spectroscopy for chemical analysis. The deposited minerals were composed of $\mathrm{Ca}$ and $\mathrm{P}$, as revealed by $\mathrm{ESCA}$. The $\mathrm{Ca} / \mathrm{P}$ ratio was approximately 1.70 , which corresponded with the value of hydroxyapatite (Fig. 8).

Growth properties. The dose of $10^{-6} \mathrm{M}$ Dex had no effect on the cell number of SV-HFO cells (Fig. 9) and BrdU incorporation (data not shown).

ALP activity and levamisole treatment. As shown in Fig. 10, 10-6 $\mathrm{M}$ Dex significantly increased ALP activity in the SV-HFO cells at days 7, 14, 21 and 28 . The maximal activity was an over 10 -fold increase at day 7 , which then decreased during culture (Fig. 10). The effect of Dex on ALP was dose-dependent (data not shown).

To elucidate the role of ALP in mineralization of SVHFO cells, the cells were cultured in the presence of $10^{-6} \mathrm{M}$ Dex and $10^{-4} \mathrm{M}$ levamisole. To avoid the influence of cell growth on ALP activity (16), the cells were treated with the agent after reaching confluent cell density. Dex-induced mineralization of the cells was clearly
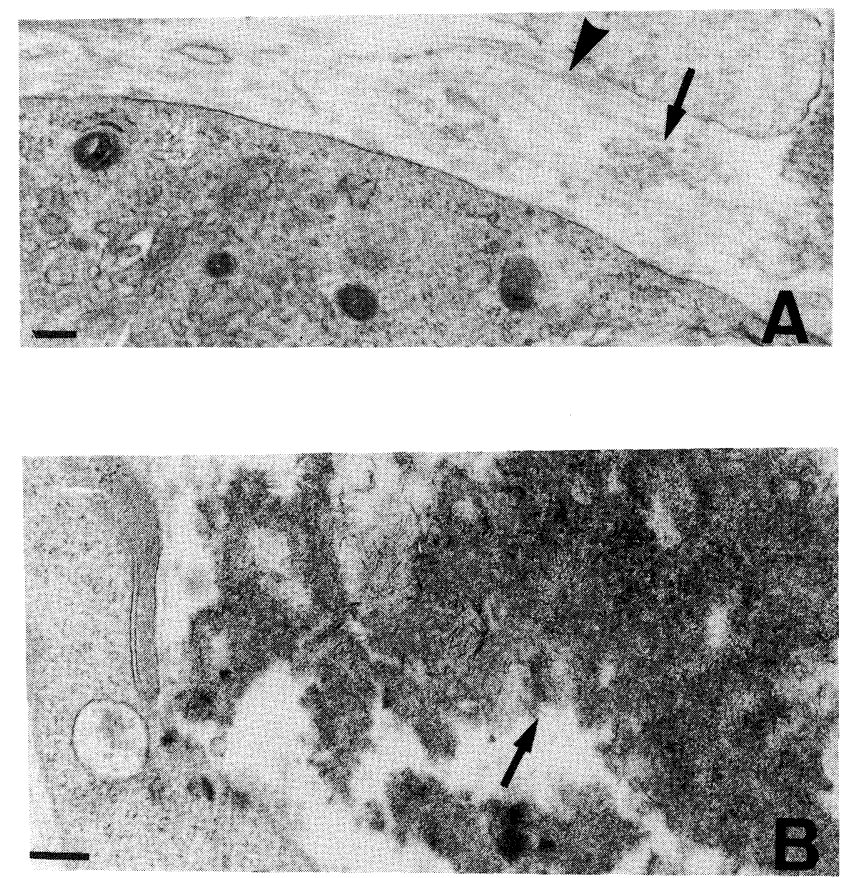

Fig. 7. Transmission electron micrographs of SV-HFO cells cultured with $10^{-6} \mathrm{M}$ Dex for 14 days, indicating electron-dense deposits (arrows) among the collagen fibrils (arrowhead). Bar, $200 \mathrm{~nm}$.

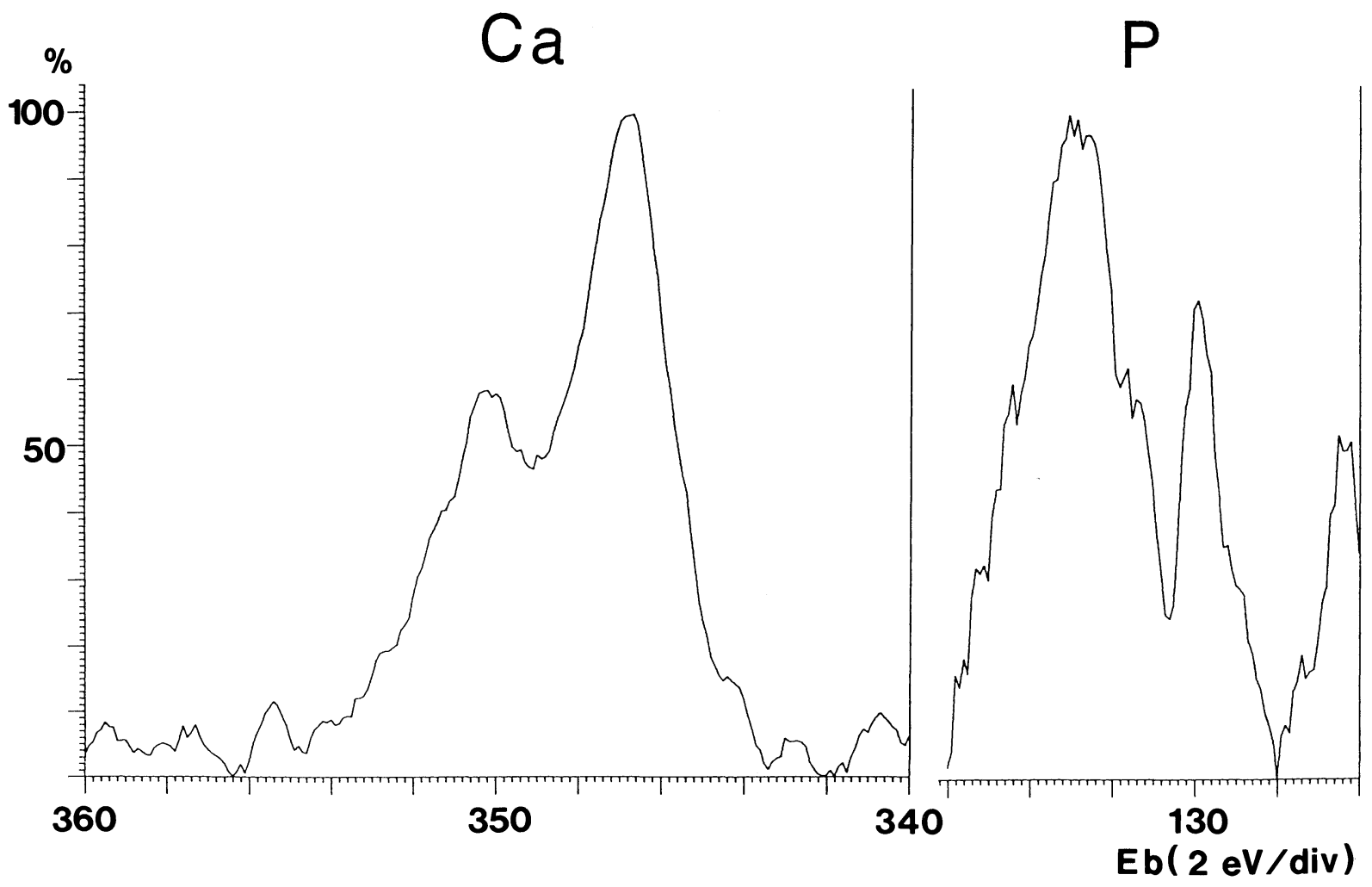

Fig. 8. Electron spectroscopic analysis of mineralized tissue of SV-HFO cells cultured with $10^{-6} \mathrm{M}$ Dex for 28 days, showing major peaks for $\mathrm{Ca}$ and $\mathrm{P}$. 


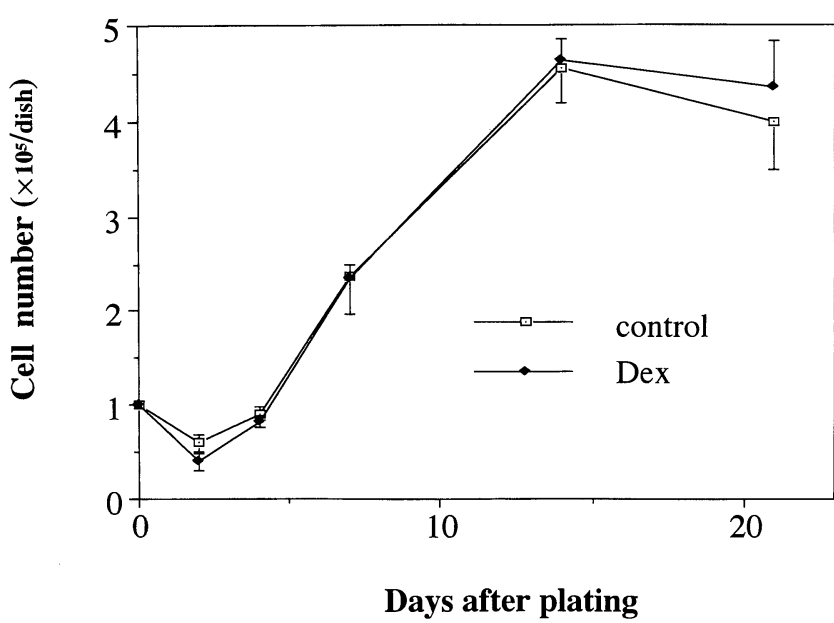

Fig. 9. Effect of $10^{-6} \mathrm{M}$ Dex on the number of SV-HFO cells. The figures show mean $\pm \mathrm{SD}$ of four different dishes with duplicate determinations. reduced when the cells were cultured in the presence of levamisole, which significantly reduced Dex-induced ALP activity to approximately the control level at the 2nd, 4th and 7th days after treatment. (Figs. 11 and 12).

Analysis of gene expression of bone differentiated proteins. We further examined the changes in the expression of ALP, Col I, ON OPN and OC mRNAs in SV-HFO cells cultured with or without $10^{-6} \mathrm{M}$ Dex (Fig. 13). Dex significantly induced the ALP mRNA expression, which was maximal at day 7 and gradually decreased, consistent with the changes in the activity of ALP during Dex-treatment. The expression of Col I and ON mRNAs, maximal at day 7, was not influenced by Dex. OPN mRNA expression was significantly induced in Dex-treated culture. In particular, 3- and 4week treatment with Dex markedly induced OPN expression, corresponding to the degree of mineralization. OC mRNA was not detected in the cells cultured with or without Dex.

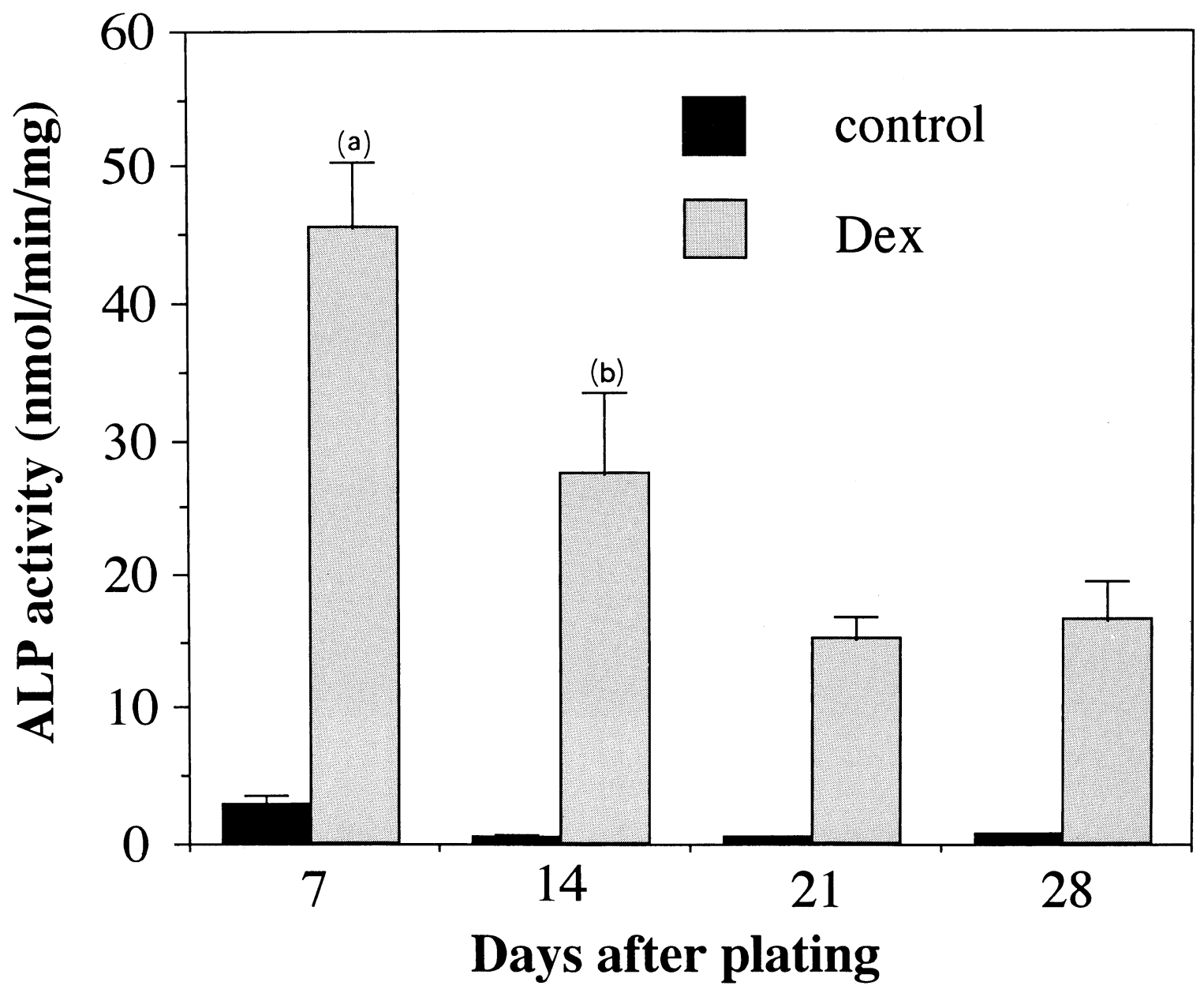

Fig. 10. Changes in ALP activity in SV-HFO cells cultured with or without $10^{-6} \mathrm{M}$ Dex for $7,14,21$ and 28 days. The figures show mean \pm SD of four different dishes with duplicate determinations. (a), (b) Significantly different from the values of cells cultured with Dex for 4 weeks ([a] $\mathrm{P}<0.001$, [b] $\mathrm{P}<0.05$ ). 


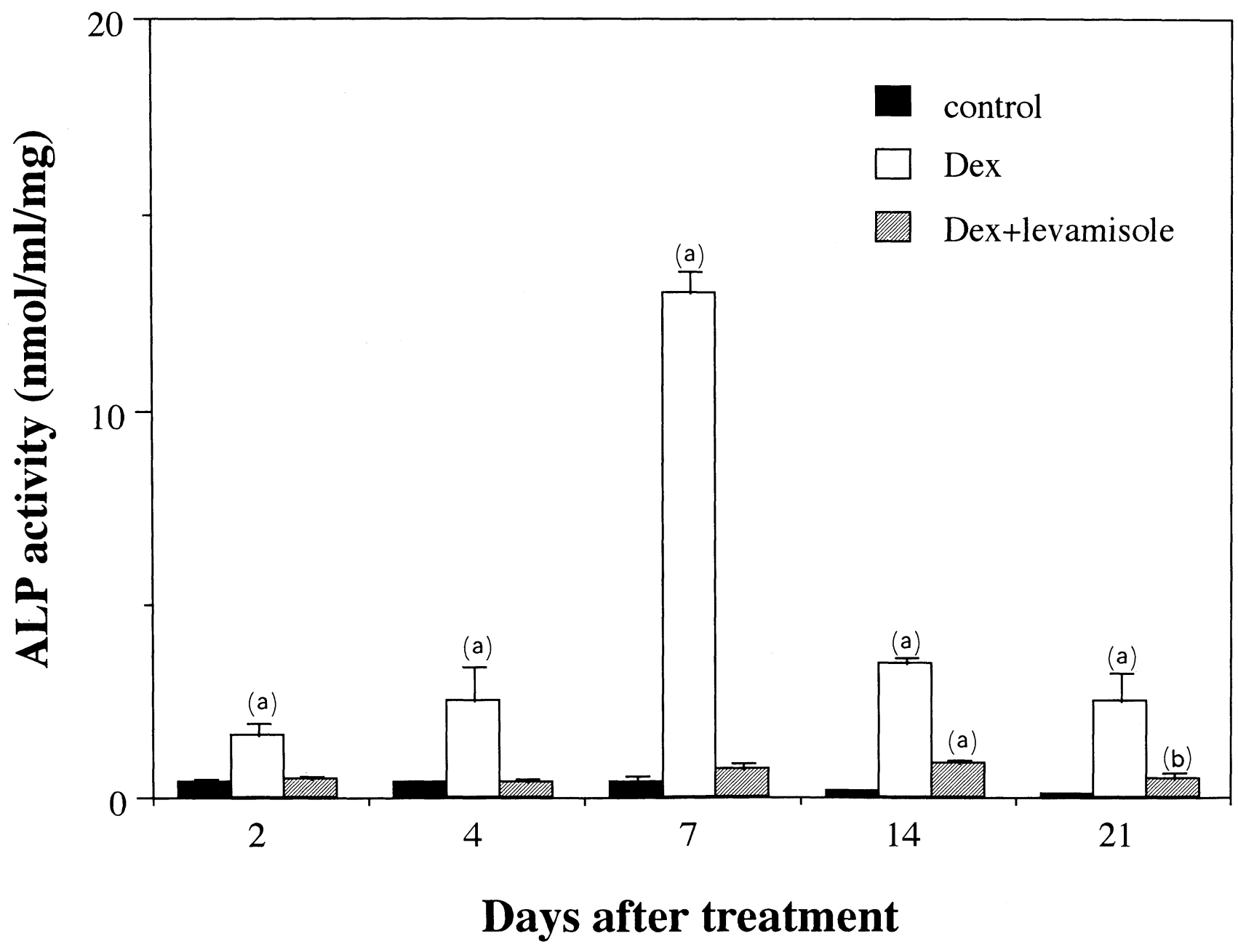

Fig. 11. Effect of levamisole on ALP activity in SV-HFO cells. The cells were treated with $10^{-6} \mathrm{M}$ Dex in the presence or absence of $10^{-4} \mathrm{M}$ levamisole for 7 days after cells confluency, and cultured without Dex and levamisole for 7 and 14 consecutive days. The figures show mean \pm SD of four different dishes with duplicate determinations. (a), (b) Significantly different from the values of cells cultured without Dex ((a) $\mathrm{P}<0.001$, (b) $\mathrm{P}<0.01$ ).

As described previously $(15,16)$, SV-HFO cells produced only a small amount of OC, a specific osteoblast differentiation marker. However, Dex did not influence $\mathrm{OC}$ synthesis during culture (data not shown).

\section{DISCUSSION}

In the present study, we showed that Dex induced mineralization of human osteoblastic cells in vitro. We also demonstrated that enhanced expression of ALP and OPN was induced in SV-HFO cells by Dex. In particular, a close relationship between the ALP expression at the early stage and the OPN expression at the late stage and mineralization was revealed.

Mineralization in the matrix of SV-HFO cells required the addition of glucocorticoids. Treatment of SV-HFO cells with Dex for only one day was sufficient for the induction of mineralization that occurred at day 14 in culture, although the degree of mineralization was lower than in the cells continuously treated with Dex. For mineralization of the cells induced by Dex, 2 weeks were always needed after the beginning of treatment. It has been suggested that glucocorticoids have a permissive effect on the differentiation of osteoprogenitor cells obtained from nonhuman sources $(7-9,20,26,29,31$, 33, 50). Recently, Cheng et al. (13) have documented that glucocorticoids induce the differentiation of human bone marrow stromal cells into osteoblasts. These findings suggested that the SV-HFO cells were osteoprogenitor cells, which can be committed to mineralization by treatment with glucocorticoids.

Dex seems to have conflicting effects on cell growth in human and rat culture systems. Dex stimulates the growth of osteoprogenitor cells obtained from fetal rat 

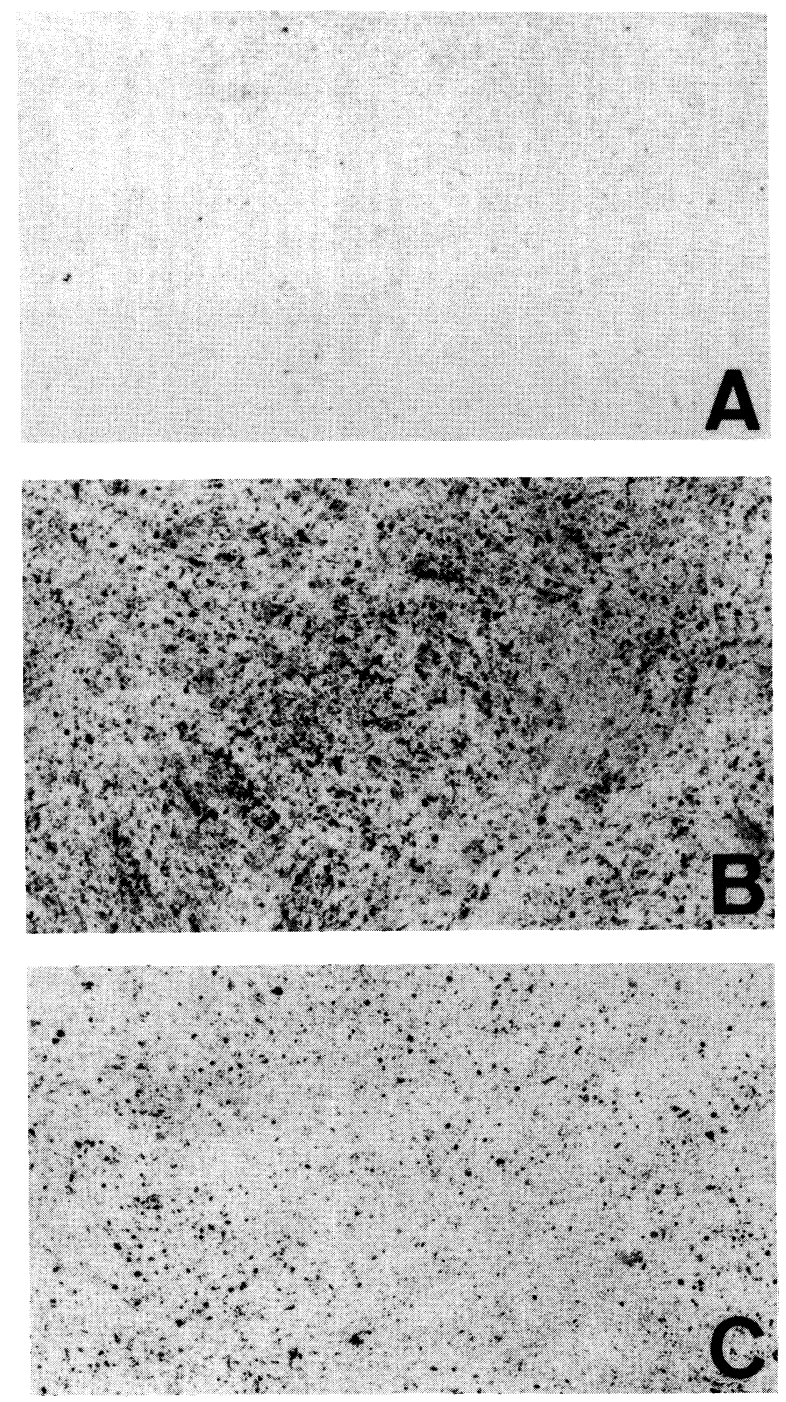

Fig. 12. Von Kossa staining of SV-HFO cells cultured under the following conditions. (A) Cells cultured without Dex and levamisole for 21 days; (B) Cells treated with $10^{-6} \mathrm{M}$ Dex for 7 days and cultured without Dex for 14 consecutive days; (C) Cells treated with $10^{-6} \mathrm{M}$ Dex and $10^{-4} \mathrm{M}$ levamisole for 7 days and cultured without either one for 14 consecutive days.

calvaria $(1,7,38)$, whereas it inhibits proliferation of the cells isolated from human trabecular bone (48) and human bone marrow (13) in primary cultures. Thus, there might be a species difference in responsiveness of osteoblastic cells to glucocorticoids. In this study, however, the proliferation of SV-HFO cells was not influenced by Dex. This discrepancy might be explained by the hypothesis that SV-40 large $\mathrm{T}$ antigen functionally inactivates $\mathrm{Rb}$ and $\mathrm{p} 53$ proteins and interferes with the effects of growth factors or hormones on cell proliferation $(5,6)$. Furthermore, since mineralization of SVHFO cells reaching confluent cell density also requires 2

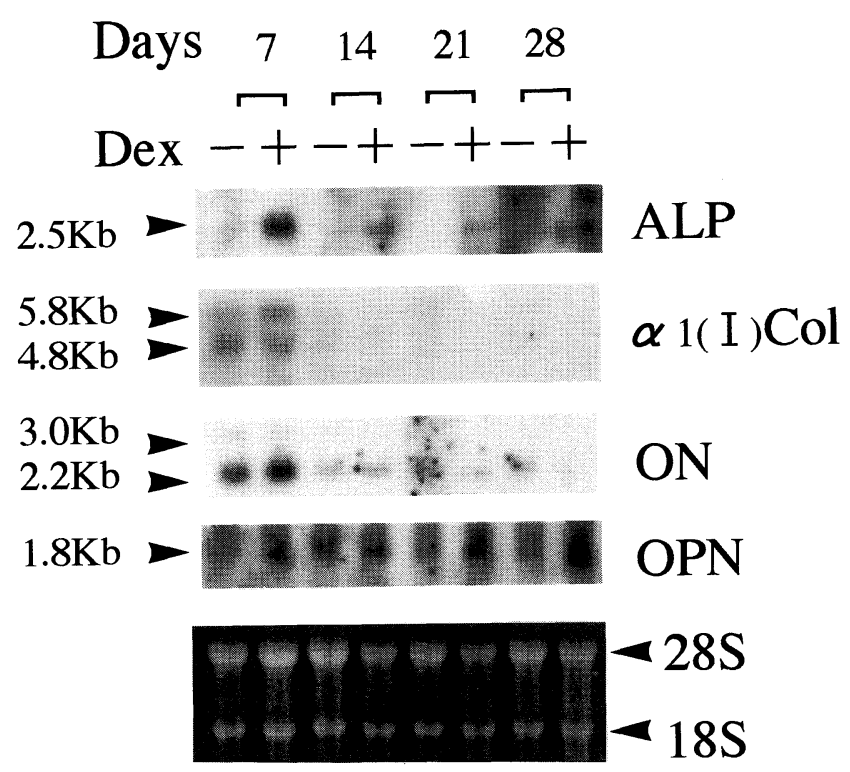

Fig. 13. Northern blot analysis of transcripts of genes of ALP, Col I, ON and OPN in SV-HFO cells cultured with or without $10^{-6} \mathrm{M}$ Dex for 7, 14, 21 and 28 days. The bottom panel shows ethidium bromide staining of the filters corresponding to $18 \mathrm{~S}$ and $28 \mathrm{~S}$ ribosomal RNAs.

weeks, Dex seems to regulate differentiation of osteoblast lineage in a manner independent of proliferative regulation.

During bone formation, osteoblasts secrete a number of bone-related proteins, many of which are integrated into the type I collagen-based scaffolding of bone matrix. Using prolonged primary cultures of fetal rat calvarial cells, Stein and coworkers described sequential events involved in this proliferation and differentiation $(38,43)$. These chronological patterns are also observed in chick $(21,41)$, mouse (39), and bovine (25) osteoblastic cells, and in rat bone marrow cells $(32,50)$. In the present study, to elucidate sequential changes in the expression of bone-related proteins during bone-like tissue formation in humans, the expression of various osteoblastic markers was examined. Of these markers, ALP activity and the expression of OPN were significantly induced by Dex, with maximal effects at day 7 and day 28 , respectively.

Dex-induced mineralization was significantly reduced when the cells were cultured with $10^{-4} \mathrm{M}$ levamisole, in which conditions Dex-induced ALP activity was reduced to approximately the control level. Under such conditions, mineralization by SV-HFO cells was significantly inhibited. These results suggest that a certain level of ALP activity in early stages is required for mineralization. Elevation of ALP activity was followed by the expression of bone-related proteins such as OPN, which are further required for the formation of bone- 
like tissues.

Several investigators have indicated, using different culture systems $(25,32,38,50)$, that the expression of OPN increases temporally, reaches its peak when mineralization begins, and then gradually decreases with mineralization. In our system, Dex induced expression of OPN with culture time at least until day 28 , corresponding to the degree of mineralization. Recently, Hirota et al. showed that the expression of OPN, not $\mathrm{ON}$, is deeply related to the degree of calcification in human atherosclerotic lesions (23). Thus, the bone matrix protein OPN may play an important role in the formation of mineral deposits in human bone tissues.

SV-HFO is the first immortalized cell line from normal human bone that forms bone-like tissues as far as we know. Since mineralization of SV-HFO cells was induced by Dex, the cells can serve as an appropriate tool for studies of the mechanisms and regulatory factors of bone formation in human bones.

Acknowledgments. We are grateful to Dr. S. Nomura (Department of Pathology, Osaka University Medical School), Dr. Y. Koshihara (Department of Biosignal Research, Tokyo Metropolitan Institute of Gerontology) and Dr. H. Isomura (Department of Pathology, Sapporo Medical University School of Medicine), for their valuable advice, and to Dr. K. Endo and Dr. H. Ohno (Department of Dental Metal Materials Science, School of Dentistry, Health Sciences of Hokkaido University), for the electron spectroscopic analysis. We also wish to thank Dr. H. Obata and Ms. E. Suzuki for their technical assistance. This study was partly supported by Grnats-in-Aids from the Ministry of Education, Culture and Science of Japan, and from the Hokkaido Geriatrics Research Institute.

\section{REFERENCES}

1. Aronow, M., Gerstenfeld, L.C., Owen, T.A., Tassinari, M.S., StEIN, G.S., and LiAN, J.B. 1990. Factors that promote progressive development of the osteoblast phenotype in cultured fetal rat calvaria cells. J. Cell. Physiol., 143: 213-221.

2. Ashton, B.A., Abdullah, F., Cave, J., Williamson, M., Sykes, B.C., Couch, M., and Poser, J.W. 1985. Characterization of cells with high alkaline phosphatase activity derived from human bone and marrow: Preliminary assessment of their osteogenicity. Bone, 6: 313-319.

3. Auf, mKolK, B., HauschKa, P.V., and Schwartz, Z. 1985. Characterization of human bone cells in culture. Calcif. Tissue Int., 37: 228-235.

4. Baran, D.T., Sorensen, A.M., Shalhoub, V., Owen, T., GARY, S., and LiAN, J. 1992. The rapid nongenomic actions of $1 \alpha, 25$-dihydroxyvitamin D3 modulate the hormone-induced increments in osteocalcin gene transcription in osteoblast-like cells. J. Cell. Biochem., 50: 124-129.

5. Bartek, J., Vojtesek, B., and Lane, D.P. 1993. Diversity of human p 53 mutants revealed by complex formation of SV40 T antigen. Europ. J. Cancer., 29A: 101-107.

6. Basolo, F., Fiore, L., Ciardiello, F., Calvo, S., Fontanini, G., Conaldi, P.G., and Toniolo, A. 1994 . Response of normal and oncogene-transformed human mammary epithelial cells to transforming growth factor $\beta_{1}$ (TGF- $\beta_{1}$ ): Lack of growth-in- hibitory effect on cells expressing the simian virus 40 large-T antigen. Int. J. Cancer., 56: 736-742.

7. Bellows, C.G., Aubin, J.E., Heersche, J.N.M., and Antosz, M.E. 1986. Mineralized bone nodules formed in vitro from enzymatically released rat calvaria cell populations. Calcif. Tissue Int., 38: 143-154.

8. Bellows, C.G., Aubin, J.E., and Heersche, J.N.M. 1987. Physiological concentrations of glucocorticoids stimulate formation of bone nodules from isolated rat calvaria cells in vitro. Endocrinology, 121: 1985-1992.

9. Benayahu, D., Kletter, Y., Zipori, D., and Wientroub, S. 1989. Bone marrow-derived stromal cell line expressing osteoblastic phenotype in vitro and osteogenic capacity in vivo. J. Cell Physiol., 140: 1-7.

10. Beresford, J.N., Gallagher, J.A., and Russell, R.G.G. 1986. 1,25-dihydroxyvitamin D3 and human bone-derived cells in vitro: Effects on alkaline phosphatase, type I collagen and proliferation. Endocrinology, 119: 1776-1785.

11. Beresford, J.N., Graves, S.E., and Sмоothy, C.A. 1993. Formation of mineralization nodules by bone derived cells in vitro: A model of bone formation. Am. J. Med. Genet., 45: 163-178.

12. Chen, P.S., Toribara, T.Y., and Warner, H. 1956. Microdetermination of phosphorus. Anal. Chem., 28: 1756-1758.

13. Cheng, S-L., Yang, J.W., Rifas, L., Zhang, S-F., and Avioli, L.V. 1994. Differentiation of human bone marrow osteogenic stromal cells in vitro: Induction of the osteoblast phenotype by dexamethasone. Endocrinology, 134: 277-286.

14. Chiba, H., Sawada, N., Ono, T., IshiI, S., and Mori, M. 1993. Establishment and characterization of a simian virus 40immortalized osteoblastic cell line from normal human bone. Jpn. J. Cancer Res., 84: 290-297.

15. Chiba, H., Sawada, N., Iba, K., Isomura, H., Ishil, S., and MoRI, M. 1993. A newly established cell line from normal human bone responds to $1 \alpha, 25$-dihydroxyvitamin $\mathrm{D} 3$, retinoic acid and transforming growth factor- $\beta_{1}$. Tumor Res., 28: 41-50.

16. Chiba, H., Sawada, N., Oyamada, M., Kojima, T., Nomura, S., IsHII, S., and MoRI, M. 1993. Relationship between the expression of the gap junction protein and osteoblast phenotype in a human osteoblastic cell line during cell proliferation. Cell Struct. Funct., 18: 419-426.

17. Chiba, H., Sawada, N., Oyamada, M., Kojima, T., Iba, K., ISHII, S., and MoRI, M. 1994. Hormonal regulation of connexin 43 expression and gap junctional communication in human osteoblastic cells. Cell. Struct. Funct., 19: 173-177.

18. ChOMCZYNSKi, P. and SACCHI, N. 1987. Single-step method of RNA isolatin by acid guanidinium thiocyanate-phenolchloroform extraction. Anal. Biochem., 162: 156-159.

19. Civitelli, R.C., Beyer, E.C., Warlow, P.M., Robertson, A.J., Geist, S.T., and Steinberg, T.H. 1993. Connexin 43 mediates direct intercellular communication in human osteoblastic cell networks. J. Clin. Invest., 91: 1888-1896.

20. Freid, A., Benayahu, D., and Weintroub, S. 1993. Marrow stroma-derived osteogenic clonal cell lines: Putative stages in osteoblastic differentiation. J. Cell. Physiol., 155: 472-482.

21. Gerestenfeld, L.C., Chipman, S.D., Glowacki, J., and Lian, J.B. 1987. Expression of differentiated function by mineralizing cultures of chicken osteoblasts. Dev. Biol., 122: 49-60.

22. Gitelman, H.J. 1967. An improved automated procedure for the detemination of calcium in biological specimens. Anal. Biochem., 18: 521-531.

23. Hirota, S., Imakita, M., Kohri, K., Ito, A., MoriI, E., Adachi, S., Kim, H., Kitamura, Y., Yutani, C., and Nomura, 
S. 1993. Expression of osteopontin messenger RNA by macrophages in atherosclerotic plaques. Am. J. Pathol., 143: 10031008.

24. Höltke, H.J., Sanger, G., Kessler, C., and Schmitz, G. 1992. Sensitive chemiluminescent detection of digoxigenin-labeled nucleic acids: A fast and simple protocol and its applications. Biotechniques, 12: 104-113.

25. Ibaraki, K., Termine, J.D., Whitson, W.S., and Young, M.F. 1992. Bone matrix m RNA expression in differentiating fetal bovine osteoblasts. J. Bone Miner. Res., 7: 743-754.

26. Kamalia, N., McCulloch, C.A.G., Tnenbaum, H.C., and LIMEBACK, H. 1992. Dexamethasone recruitment of self-renewing osteoprogenitor cells in chick bone marrow stromal cell cultures. Blood, 179: 320-326.

27. Keeting, P.H., Scott, R.E., Colvard, D.S., Anderson, M.A., Oursler, M.J., Spelsberg, T.C., and Riggs, B.L. 1992. Development and characterizationf of rapidly proliferating, well-differentiated cell line derived from normal adult human osteoblast-like cells transfected with SV40 large T antigen. J. Bone Miner. Res., 7: 127-136.

28. Koshihara, Y., Kawamura, M., Oda, H., and Higaki, S. 1987. In vitro calcification in human osteoblastic cell line derived from periosteum. Biochem. Biophys. Res. Commun., 145: 651-657.

29. Leboy, P.S., Beresford, J.N., Devin, C., and Owen, M.E. 1991. Dexamethasone induction of osteoblast mRNA in rat marrow stromal cell cultures. J. Cell. Physiol., 146: 370-378.

30. Long, M.W., Williams, J.L., and ManN, K.G. 1990. Expression of human bone-related proteins in the hematopoietic microenvironment. J. Clin. Invest., 86: 1387-1395.

31. Mcculloch, C.A.G. and Tenenbaum, H.C. 1986. Dexamethasone induces proliferation and terminal differentiation of osteogenic cells in tissue culture. Anat. Rec., 215: 397-402.

32. Malaval, L., Modrowski, D., Gupta, A.K., and Aubin, J.E. 1994. Cellular expression of bone-related proteins during in vitro osteogenesis in rat bone marrow stromal cell cultures. $J$. Cell. Physiol., 158: 555-572.

33. Maniatopoulos, C., Sodek, J., and Melscher, A.H. 1988. Bone formation in vitro by stromal cells obtained from bone marrow of young adults rats. Cell Tissue Res., 254: 317-330.

34. Matumoto, T., Igarashi, C., Takeuchi, Y., Harada, S., Kikuchi, T., Yamato, H., and Ogata, E. 1991. Stimulation by 1,25-dihydroxyvitamin $\mathrm{D} 3$ of in vitro mineralization induced by osteoblast-like MC3T3-E1 cells. Bone, 12: 27-32.

35. Mayahara, H., Ito, T., Nagai, H., Miyajima, H., Tsukuda, R., TaKetomi, S., Mizoguchi, J., and Kato, K. 1993. In vivo stimulation of endosteal bone formation by basic fibroblast growth factor in rats. Growth Factors, 9: 73-80.

36. Noda, M. and CAmilliere, J. 1989. In vivo stimulation of bone formation by transforming growth factor- $\beta$. Endocrinology, 124: 2991-2994.

37. Noff, P., Pitaru, S., and Savion, N. 1989. Basic fibroblast growth factor enhances the capacity of bone marrow cells to form bone-like nodule in vitro. FEBS. Lett., 250: 619-621.

38. Owen, T.A., Aronow, M., Shalhoub, V., Barone, L.M., Wilming, L., Tassinari, M.S., Kennedy, M.B., Pockwinse, S., Lian, J.B., and Stein, G.S. 1990. Progressive development of the rat relationship in expression of genes associated with osteoblast proliferation and differentiation during formation of the bone extracellular matrix. J. Cell. Physiol., 143: $420-430$.
39. Quarles, L.D., Yohay, D.A., LeVer, L.W., Caton, R., and WenSTRUP, R.J. 1992. Distinct proliferative and differentiated stages of murine MC3T3-E1 cells in cultures: An in vitro model of osteoblast development. J. Bone Miner. Res., 7: 683-692.

40. Robey, P.G. and Termine, J.P. 1985. Human bone cells in vitro. Calcif. Tissue Int., 37: 453-460.

41. Shalhoub, V., Conoln, D., Tassinari, M., Quinn, C., PARTRIDGe, N., Stein, G.S., and Lian, J.B. 1992. Glucocorticoids promote development of the osteoblast phenotype by selectively modulating expression of cell growth and differentiation associated genes. J. Cell. Biochem., 50: 425-440.

42. Sodek, J. and Berkman, F.A. 1987. Bone cell cultures. In: Methods in Enzymology. J.H. Low and H.C. Rilling, eds. Academic Press, San Diego, Vol. 145, pp. 303-324.

43. Stein, G.S., Lian, J.B., and Owen, T.A. 1990. Relationship of cell growth to the regulation of tissue-specific gene expression during osteoblast differentiation. FASEB J., 4: 3111-3123.

44. Swaroop, A., Hogan, B.L.M., and Francke, V. 1988. Molecular analysis of the cDNA for human SPARC/osteonectin/BM-40: Sequence, expression, and localization of the gene to chromosome 5q31-q33. Genomics, 2: 37-47.

45. Ueno, K., Katayama, T., Miyamoto, T., and Koshihara, Y. 1992. Interleukin-4 enhances in vitro mineralization in human osteoblast-like cells. Biochem. Biophys. Res. Commun., 189: 1521-1526.

46. Vlasselaer, P.V., Borremans, B., van Gorp, U., Dasch, J.R., and De WAAL-MALEFYT, R. 1994. Interleukin 10 inhibits transforming growth factor- $\beta$ (TGF- $\beta$ ) synthesis required for osteogenic commitment of mouse bone marrow cells. J. Cell. Biol., 124: $569-577$.

47. Wong, G. 1990. Isolation and behavior of isolated bone-forming cells. In: Bone. B.K. Hall, Ed. The Telford Press, Caldwell, Vol. 1, pp. 171-179.

48. Wong, M-M., Rao, L.G., Ly, H., Hamilton, L., Tong, J., Sturtridge, W., McBroom, R., Aubin, J.E., and Murray, T.M. 1990. Long-term effects of physiologic concentrations of dexamethasone on human bone-derived cells. J. Bone Miner. Res., 5: 803-813.

49. XIE, W. and Rothblum, L.I. 1991. Rapid, small-scale RNA isolation from tissue culture cells. BioTechniques, 11: 325-327.

50. Yao, K., Todescan, Jr., R., and SodeK, J. 1994. Temporal changes in matrix protein synthesis and mRNA expression during mineralized tissue formation by adult rat bone marrow cells in culture. J. Bone. Miner. Res., 9: 231-240.

51. Young, M.F., Kerr, J.M., Termin, J.D., Wewer, U.M., WANG, M.G., McBridge, O.W., and Fisher, L.W. 1990. cDNA cloning, mRNA distribution and heterogeneity, chromosomal location, and RFLP analysis of human osteopontin (OPN). Genomics, 7: 491-502.

(Received for publication, April 25, 1995 and in revised form, June 27, 1995) 